\title{
FISH IMMUNE RESPONSE TO MYXOZOAN PARASITES
}

\author{
SITJÀ-BOBADILLA A.*
}

\section{Summary :}

Myxozoan parasites are responsible for important economic losses among fisheries and aquaculture industries, and hence the high interest in studying the immune response of fish against them. The most important data available concerning the immune response of fish against myxosporeans are reviewed, with emphasis on the different innate and adaptive immune mechanisms, their relationship with natural and acquired resistance and the strategies to control and prevent myxosporoses. Cellular effectors (lymphocytes, granulocytes, phagocytes, non-specific cytotoxic cells, rodlet cells) and humoral factors (lysozyme, peroxidades, antiproteases, complement, specific antibodies) have been examined for several myxosporoses, and some immune relevant genes have been studied. This information will be crucial for the future development of vaccines and other preventive strategies such as immunomodulation and selection of disease-resistant strains

KEY WORDS : Immune response, fish parasites, Myxosporea.

T The Myxozoan phylum gathers more than 2,180 species, being most of them fish parasites, though their presence has also been documented in waterfowl, amphibians, reptiles and even mammals (Lom \& Dyková, 2006). Myxozoa are long-known organisms, which still today pose important questions about their origin, phylogenetic relationship and life cycle (Kent et al., 2001; Fiala, 2006). They are responsible for important economic losses among fisheries and aquaculture industries, and hence the high interest in studying the immune response of fish against them. However, research in this group of multicellular organisms is held back by the lack of in vitro cultures and the difficulty to set up experimental transmission models. Although the fish immune response has some special features, a functional parallelism between fish and mammalian system is increasingly confirmed by recent findings, and both innate and adaptive immune effectors against parasites do exist in teleosts. This review is focused on the most important data available concerning the immune response of fish against myxo-

\footnotetext{
* Instituto de Acuicultura de Torre de la Sal, Consejo Superior de Investigaciones Científicas, Torre de la Sal s/n, 12595 Ribera de Cabanes, Castellón, Spain.

Correspondence: Dr Ariadna Sitjà-Bobadilla.

Tel.: +34 964319500 - Fax: +34 964319509

E-mail: ariadna@iats.csic.es
}

sporeans, with emphasis on the different innate and adaptive immune effectors, their relationship with natural and acquired resistance and the strategies to control and prevent myxosporoses.

\section{NON-SPECIFIC IMMUNE RESPONSE}

\section{Cellular immune ResPonse}

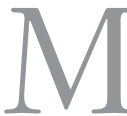
any myxosporean species cause little or no host response, especially coelozoic ones. In some cases, the absence of cellular reaction is due to their development in immunoprivileged sites (such as the central nervous system, eyes or gonads), where the immune system has particular or reduced functions. It has been shown that penetrating triactinomyxon-sporoplams of Myxobolus cerebralis reach the cartilage via peripheral nerves and the central nervous system (El-Matbouli et al., 1995). It seems plausible that the actinosporean stage uses this penetrating route to avoid immune response to multiply in high numbers before reaching other hostile sites. Similarly, Sphaerospora testicularis exploits efficiently the immune-privileged condition of the seminiferous tubules of European sea bass (Dicentrarchus labrax). It proliferates within their lumen without the interference of any cellular reaction (Sitjà-Bobadilla \& Alvarez-Pellitero, 1993). On the other hand, some myxosporeans invoke an excessive inflammatory response leading to an immunopathological condition, as in Tetracapsuloides bryosalmonae-infected rainbow trout, in which the proliferation of lymphocytes is the major cause of renal tissue hyperplasia (Chilmonczyk et al., 2002). The same happens in Ceratomyxa shasta-infected fish, which develop a vigorous host response, consisting of lymphocytes and eosinophilic granular leucocytes (Bartholomew et al., 1989). Some authors have pointed out that severe inflammatory reactions are found in abnormal hosts for the myxosporean (Kent \& Hedrick, 1985). The commonest picture observed in histopathological studies is the encapsulation of the parasitic stages by connective, fibrotic and epitheliod tissue layers, which is aimed to isolate the parasite and to prevent its dis- 
persal to surrounding tissues (Davies \& Sienkoswki, 1988). These granulomata are often accompanied by melanomacrophage centres, and their presence can also be increased in head kidney and spleen. However, the efficacy of this encapsulation could be limited, as in Myxobolus pendula in which the capsule does not appear to inhibit diffusion of oxygen and nutrients to the parasite (Koehler et al., 2004), or in S. testicularis infected sea bass testis, in which the large granulomata reduce the areas of germinal tissue up to the next spawning season (Sitjà-Bobadilla \& Alvarez-Pellitero, 2003).

Several cellular types are involved in the response against myxosporeans. Rodlet cells (RC) are among them, as they are generally increased in infected tissues or have been observed in close vicinity to myxosporeans, some times even discharching their rods (Leino, 1996; Palenzuela et al., 1999; Muñoz et al., 2000a). By contrast, RC are very scarce in D. puntazzo, even when infected by E. leei (Alvarez-Pellitero et al., 2007). RC are thought to be connected with inflammatory cells and host defence against parasites (Reite, 2005), but their function is still controversial and their specific role in myxosporean infections is unknown. In addition, different types of leucocytes and their functions have been studied in several myxosporoses. Mononuclear inflammatory cells were present in perichondral and periosteal connective tissue foci, but were notably absent in areas of cartilage necrosis due to Myxobolus byborbynchi (Cone \& Frasca, 2002). Phagocytes and granulocytes were present in the ascitic fluid of European sea bass infected by $S$. testicularis (Sitjà-Bobadilla \& Alvarez-Pellitero, 1993). Eosinophilic granular cells and other granulocytes can be increased at the site of the infection (intestine) (Alvarez-Pellitero et al., 2007) or in blood (Sitjà-Bobadilla et al., 2006) in enteromyxosis, but its presence can be decreased in haematopoietic organs such as head kidney and spleen (Cuesta et al., 2006b, Alvarez-Pellitero et al., 2007). Also the number and distribution of lymphocytes can be altered by enteromyxosis in turbot, with a significant decrease of the percentage of circulating lymphocytes (Sitjà-Bobadilla et al., 2006), and in the number of $\mathrm{Ig}^{+}$ cells in head kiney and spleen (Bermúdez et al., 2006), whereas its number was increased at intestine (Bermúdez et al., 2006).

The respiratory burst of phagocytes plays an important role in the fight against parasites, and their activity can be modulated by myxosporean infections. Some enteromyxosis induce an increase in the respiratory burst of circulating phagocytes (Alvarez-Pellitero et al., 2007; Sitjà-Bobadilla et al., 2006), but a decrease in the activity of head kidney phagocytes (Cuesta et al., 2006b). Furthermore, it has been demonstrated in vitro that the addition of a myxosporean parasite induces the production of reactive oxygen species
(Muñoz et al., 2000b). By constrast, other myxosporean infections invoke a depressed function of phagocytes (Chilmonczyk et al., 2002) or lymphocytes (Densmore et al., 2004). Reactive nitrogen intermediates are also produced by activated phagocytes and are also cytotoxic effector molecules against fish pathogens. In E. leeiinfected sharpsnout sea bream, serum nitric oxide values were gradually increased after exposure to the parasite (Golomazou et al., 2006). In addition, cell-mediated cytotoxicity due to non-specific cytototoxic cells was also increased in $E$. leei-exposed gilthead seabream (Cuesta et al., 2006b).

\section{HumOral IMMUNE RESPONSE}

Some humoral innate factors such as peroxidases (PO), lysozyme (LY) or complement can partake in direct fish pathogen elimination, and the data obtained in myxosporean infections are quite variable depending on the host-parasite model. Concerning serum PO, in E. leeiexposed sharpsnout sea bream, the levels were higher than in non-exposed ones (Muñoz et al., 2007), whereas serum and HK leucocyte PO depletion was reported in E. leei-exposed gilthead sea bream (Cuesta et al., 2006a,b). Regarding LY activity, there was a significant depletion in gilthead sea bream naturally infected by Polysporoplasma sparis (Karagouni et al., 2005) and in E. leei-exposed gilthead sea bream (author's unpublished observations). However, in sharpsnout sea bream no LY could be detected in either infected or healthy animals (Golomazou et al., 2006; Alvarez-Pellitero et al., 2007), and it has been suggested that its absence could contribute to the high pathogenicity of this myxosporean in this host (Alvarez-Pellitero et al., 2007). In contrast, in other myxosporean infections or immunizations, LY levels can be increased (Muñoz et al., 2000a; Sitjà-Bobadilla et al., 2006; Foott et al., 2004). The information on fish serum complement in myxosporean infections is scarce and it can be quite variable depending on the host-parasite model and the timing of the infections. Plasma complement activity of infected salmon was not altered until ceratomyxosis was quite advanced (Foott et al., 2004). In Enteromyxum spp. infections, the activity of the complement alternative pathway is initially increased and/or unaltered in response to the parasite exposure, but later on consumed to fight it (Cuesta et al., 2006a; Sitjà-Bobadilla et al., 2006; Alvarez-Pellitero et al., 2007). It has also been suggested that some parasite-specific glycans may activate the complement system through the lectin pathway (Kaltner et al., 2007).

$\alpha-2 \mathrm{M}$ is a versatile anti-protease capable of trapping and functionally silencing all classes of microbial and parasite proteases. Increased serum total antiproteases and serum $\alpha-2 \mathrm{M}$ were found in $E$. leei-parasitized sharpsnout sea bream (Muñoz et al., 2007) and E. scoph- 
thalmi-parasitized turbot (Sitjà-Bobadilla et al., 2006), respectively. These data suggest a role in counteracting the putative action of parasite proteases at the local level.

\section{SPECIFIC IMMUNE RESPONSE}

$\mathrm{D}$ uring decades, it was thought that fish were unable to mount an adaptive or specific immune response against Myxosporea, as the first works failed to detect specific antibodies (Pauley, 1974; Halliday, 1974; Siau, 1980; Bartholomew et al., 1989), and a theory of the antigenic mimicry of the parasite was even proposed (McArthur \& Sengupta, 1982). However, nowadays, the presence of specific antibodies has been unambiguously reported in fish infected by the myxosporeans Myxobolus cerebralis (Hedrick et al., 1998), Myxobolus artus (Furuta et al., 1993), Tetracapsuloides bryosalmonae (Saulnier \& Kinkelin, 1996), Ceratomyxa shasta (Bartholomew, 2001) and Enteromyxum scophthalmi (Sitjà-Bobadilla et al., 2004). The speed of antibody production is relatively low in comparison with available data for other fish immunized or vaccinated with different parasites. Thus, in rainbow trout exposed to $M$. cerebralis, specific antibodies were not present until 12 weeks after exposure (Ryce, 2003), whereas anti-PKX antibodies were detected as early as six weeks p.e. (Hedrick et al., 1991). When turbot were challenged with E. scophthalmi, specific antibodies were detected as soon as 48 days p.e. if fish belonged to previously exposed stocks (Sitjà-Bobadilla et al., 2007b), whereas if fish belonged to naïve stocks, they developed the disease and died without producing antibodies at 40-49 days p.e. (Redondo et al., 2002; SitjàBobadilla et al., 2006).

\section{INNATE AND ACQUIRED RESISTANCE TO MYXOSPOROSIS}

$\mathrm{N}$ atural or innate resistance of certain fish species and strains against Myxosporea has been reported, but the mechanisms involved in such complex phenomenon have not been elucidated in most cases. Concerning inter-specific differences, they have been documented for C. shasta (Bartholomew, 1998) and for M. cerebralis (Hedrick et al., 1998; Blazer et al., 2004) among salmonid species. Based on epizootiological data, Sugiyama et al. (1999) indicated that amberjack (Seriola dumerili) was less susceptible to Kudoa amamiensis than yellowtail (Seriola quinqueradiata). Data obtained from proliferative kidney disease (PKD) experimental infections indicate that the deve- lopment of the parasite and the severity of the disease may vary with host salmonid species (Arkush \& Hedrick, 1990). For E. leei, some aquarium (Padrós et al., 2001) and fresh water (Diamant et al., 2006) fish are refractory to infection, and among susceptible species, a range of pathogenic effect has also been documented. Thus, in gilthead sea bream this enteromyxosis can be considered a slow-progressing disease, as external symptoms and mortality usually begin two months or later on after exposure to the pathogen (Sitjà-Bobadilla et al., 2006). By contrast, in other susceptible species, such as sharpsnout sea bream (Diplodus puntazzo) (Golomazou, et al., 2006; Alvarez-Pellitero et al., 2007) and Japanese flounder (Paralichthys olivaceus) initial signs of infection and mortality were detected earlier (Yasuda et al., 2005). At the other end of the range, European sea bass stands as a low susceptible species, since the infection progresses even more slowly than in gilthead sea bream and fish did not die nor show any of the typical disease signs of enteromyxosis (SitjàBobadilla et al., 2007a). Similarly, E. scophthalmi which is highly pathogenic for turbot, seems to be less harmful for sole (Solea senegalensis), as experimentally infected fish and cultured stocks have much lower infection levels than turbot ones and infected fish did not show typical emaciative signs (Palenzuela et al., 2007). Regarding intra-specific differences in susceptibility, turbot stocks of different origin exhibited different susceptibility to E. scophthalmi in natural (Quiroga et al., 2006) and experimental (Sitjà-Bobadilla et al, 2006) infections. Similarly, field and experimental data suggest that some gilthead sea bream stocks are partially resistant to E. leei (Jublanc et al., 2006; Sitjà-Bobadilla et al., 2007a). Differences in resistance to C. shasta within strains of some salmonid species are documented (Bartholomew, 1998), as well as to $M$. cerebralis within different strains of rainbow trout (Hedrick et al., 2003), cutthroat trout (Wagner et al., 2002) and steelhead (Densmore et al., 2001). However, strains of O. mykiss resistant to $C$. shasta are susceptible to $M$. cerebralis, suggesting that different mechanisms might be involved in the resistance to each myxosporean (Hedrick et al., 2001). Based on epizootiological data, some Salmo salar stocks appear to be more resistant to PKD (Quigley \& McArdle, 1998), and some carp species have been suggested to be less susceptible to Thelohanellus nikolskii (Molnár, 2002).

The association between the production of specific antibodies and acquired immunity in fish has been demonstrated for several protozoan and metazoan parasites. However, acquired resistance has been linked to specific immune response only for two myxosporeans. In turbots surviving E. scophthalmi epizootic outbreaks, when experimentally challenged for a second time, a negative relationship between the development of the disease and the presence of antibodies was found 
(Sitjà-Bobadilla et al., 2007b). By contrast, for M. cerebralis, acquired immunity was found only among previously exposed fish that developed active infections (Hedrick et al., 1998). Similarly, trout which had recovered from clinical PKD infections were found to be resistant to reinfection. Resistant was induced by active infection and not just previous exposure (Foott \& Hedrick, 1987). D. puntazzo recovered from E. leei infection, when challenged with the parasite again were refractive to the disease, indicating possibly the development of immunity against the parasite (Golomazou et al., 2006)

This protective specific immune response is probably accompanied by a repertoire of non-specific immune factors. In fact, they have been suggested as the main mechanism limiting the establishment of ceratomyxosis (Bartholomew, 1998), and contributing to the resistance of rainbow trout M. cerebralis (Ryce, 2003). In turbot enteromyxosis, antibody response takes about 50-100 days to appear (Sitjà-Bobadilla et al., 2005; 2007b), whereas some cellular and humoral effectors can be affected from day 20 p.e. (Sitjà-Bobadilla et al., 2006). Thus, the activation of a cascade of events involving different innate immune factors in a first line of combat may lead to the production of specific antibodies in a further step.

\section{FUTURE RESEARCH PERSPECTIVES}

O haracterization of the fish immune system and its regulation is crucial for the development of vaccines and other preventive strategies such as immunomodulation and selection of disease-resistant strains. As shown above, some aspects of the humoral and cellular immune responses against myxosporeans have been studied, but information on the molecular mechanisms involved in such immune defence is almost null. Recently, data on the expression of immunorelevant genes in fish experimentally infected by the myxosporeans T. bryosalmonidae (Holland et al., 2003), M. cerebralis (Severin \& El-Matbouli, 2007) and E. leei (Cuesta et al., 2006a) has been published, but still many questions wait to be answered.

The exploitation of the immune system through breeding selection programmes is a promising future strategy to control myxosporoses, but much work is still to be done concerning the selection of resistant strains, as in most cases the genetic base is unknown. For C. shasta, multiple gene loci have been found associated to resistance in O. mykiss (Nichols et al., 2003), for $M$. cerebralis, inheritance of resistance in disease resistant rainbow has been shown (Schisler et al., 2006), and for PGD a genetic component for resistance in catfish has been suggested (Bosworth et al., 2003).

\section{ACKNOWLEDGEMENTS}

1 art of the information gathered in the present review has been generated in projects funded by EU and the Spanish Ministerio de Educación y Ciencia through research projects MyxFishControl (QLRT2001-00722) and AGL2006-13158-C02-01.

\section{REFERENCES}

Alvarez-Pellitero P., Palenzuela O. \& Sitjà-Bobadilla A. Histopathology and cellular response in Enteromyxum leei (Myxozoa) infections of Diplodus puntazzo (Teleostei). Parasitol. Int., 2008, 57, 110-120.

ARKusH K.D. \& HedRICK RP. Experimental transmission of PKX, the causative agent of proliferative kidney disease, to three species of Pacific salmon. J. Appl. Ichthyol., 1990, 6, 237-343

Bartholomew J.L. Host resistance to infection by the Myxosporean parasite Ceratomyxa shasta: a review. J. Aquat. Anim. Health., 1998, 10, 112-20.

Bartholomew J.L. Parasites, their hosts and why disease occurs (or doesn't?). 131 $1^{\text {st }}$ Ann Meet Am Fish Soc, Phoenix, AZ, Aug 20-24, 2001.

Bartholomew J.L., Smith C.E., Rohovec J.S \&. Fryer J.L. Characterization of a host response to the myxosporean parasite, Ceratomyxa shasta (Noble), by histology, scanning electron microscopy and immunological techniques. J. Fish. Dis., 1989, 12, 509-522.

Bermúdez R., Vigliano F., Marcaccini A., Sitjà-Bobadilla A., Quiroga M.I. \& Nieto J.M. Response of Ig-positive cells to Enteromyxum scophthalmi (Myxozoa) experimental infection in turbot, Scophthalmus maximus (L.): a histopathological and immunohistochemical study. Fish \& Shellfish Immunol., 2006, 21, 501-512.

Blazer V.S., Densmore C.L., Schill W.B., Cartwright D.D. \& PAGE S.J. Comparative susceptibility of Atlantic salmon,lake trout and rainbow trout to Myxobolus cerebralis in controlled laboratory exposures. Dis. Aquat. Organ., 2004, 58, 2734.

Bosworth B.G., Wise D.J, Terhune J.S. \& Wolters W.R. Family and genetic group effects for resistance to proliferative gill disease in channel catfish $\mathrm{x}$ blue catfish backcross hybrids. Aquacult. Res., 2003, 34, 569-573.

Chilmonczyk S., Monge D. \& DE Kinkelin P. Proliferative kidney disease: cellular aspects of the rainbow trout, Oncorhynchus mykiss (Walbaum), response to parasitic infection. J. Fish. Dis., 2002, 25, 217-26.

Cone D.K. \& Frasca S. Revised diagnosis, site of development, and lesions due to Myxobolus byborbynchi (Myxоzoa) parasitizing fathead minnow in Minnesota. J. Aquat. Anim. Health, 2002, 14, 209-215.

Cuesta A., Muñoz P., Rodríguez A., Salinas I., SitjÀ-Bobadilla A., Alvarez-Pellitero P., Esteban M.A. \& Meseguer J. Gilthead seabream (Sparus aurata) innate defence against the parasite Enteromyxum leei (Myxozoa). Parasitology, 2006a, 132, $1-10$ 
Cuesta A., Salinas I., Rodríguez A., Muñoz P., Sitjà-Bobadilla A., Alvarez-Pellitero P., Meseguer J. \& Esteban M.A. Cell-mediated cytotoxicity is the main innate immune mechanism involved in the cellular defence of gilthead seabream (Teleostei: Sparidae) against Enteromyxum leei (Myxozoa). Parasite Immunol., 2006b, 28, 657-65.

DAVIES A.J. \& SiENKOWSKI I.K. Further studies on Zschokkella russelli Tripathi (Myxozoa: Myxosporea) from Cilliata mustela L. (Teleostei: Gadidae), with emphasis on ultrastructural pathology and sporogenesis. J. Fish. Dis., 1988, 11, 325-336.

Densmore C.L., Blazer V.S., Cartwright B.D.D. \& Schill W.B. A comparison of susceptibility to Myxobolus cerebralis among strains of rainbow trout and steelhead in field and laboratory trials. J. Aquat. Anim. Health, 2001, 13, 220-7.

Densmore C.L., Ottinger C.A., Blazer V.S. \& Iwanowicz L.R. Immunomodulation and disease resistance in postyearling rainbow trout infected with Myxobolus cerebralis, the causative agent of whirling disease. J. Aquat. Anim. Health., 2004, 16, 73-82.

DiAmANT A., RAM S. \& PAPERNA I. Experimental transmission of Enteromyxum leei to freshwater fish. Dis. Aquat. Organ., 2006, 72, 171-178.

El-Matbouli M., Hoffmann R.W. \& Mandok C. Light and electron microscopic observations on the route of the triactinomyxon-sporoplasm of Myxobolus cerebralis from epidermis into rainbow trout cartilage. J. Fish. Biol., 1995, 46, 919-935.

FOOTT J.S. \& HEDRICK RP. Seasonal occurrence of the infectious stage of proliferative kidney disease (PKD) and resistance of rainbow trout, Salmo gairdneri Richardson, to reinfection. J. Fish. Biol., 1987, 30, 477-483.

FoOTT J.S., HARMON R. \& STONE R. Effect of water temperature on non-specific immune function and ceratomyxosis in juvenile chinook salmon and steelhead from the Klamath River. Calif. Fish \& Game, 2004, 90, 71-84.

Fiala I. The phylogeny of Myxosporea (Myxozoa) based on small subunit ribosomal RNA gene analysis. Int. J. Parasitol., 2006, 36, 1521-1534.

Furuta T., Ogawa K. \& Wakabayashi H. Humoral immune response of carp Cyprinus carpio to Myxobolus artus (Myxozoa: Myxobolidae) infection. J. Fish. Biol., 1993, 43, 441450.

Golomazou E., Athanassopoulou F., Karagouni E., Tsagozis P., Tsantilas H., Vagianou S. Experimental transmission of Enteromyxum leei Diamant, Lom and Dyková, 1994 in sharpsnout seabream, Diplodus puntazzo C. and the effect on some innate immune parameters. Aquaculture, 2006, 260, 44-53.

Halliday M.M. Studies on Myxosoma cerebralis, a parasite of salmonids. 4. Preliminary immunofluorescent investigation of spores of Myxosoma cerebralis. Nord. Veterinaermed., 1974, 26, 173-179.

Hedrick R.P., Wishrovsky A., Modin J.C. \& Toth R.J. Three myxosporeans found in the cranial tissues of rainbow trout in California. J. Aqua. Anim. Health., 1991, 3, 55-62.

Hedrick R.P., AdKinson M.A. \& MacConnell E. Whirling disease: re-emergence among wild trout. Immunol. Rev., 1998, 166, 365-76.
Hedrick R.P., McDowell T.S., MukKatira K., Georgiadis M.P. \& Mac-Connell E. Salmonids resistant to Ceratomyxa shasta are susceptible to experimentally induced infections with Myxobolus cerebralis. J. Aquat. Anim. Health., 2001, 13, 35-42.

Hedrick R.P., McDowell T.S., Marty G.D., Fosgate G.T., MuKkatira K., Myklebust K. \& El-Matbouli M. Susceptibility of two strains of rainbow trout (one with suspected resistance to whirling disease) to Myxobolus cerebralis infection. Dis. Aquat. Organ., 2003, 55, 37-44.

Holland J.W., Gould C.R.W., Jones C.S., Noble L.R. \& SeComBES C.J. The expression of immune-regulatory genes in rainbow trout, Oncorbynchus mykiss, during a natural outbreak of proliferative kidney disease (PKD). Parasitology, 2003, 126, S95-S102.

Jublanc E., Toubiana M., Sri Widada J., Le Breton A., LeFebvre G., Sauvegrain C. \& Marques A. Observation of a survival case following infestation by Enteromyxum leei (Myxozoa: Myxosporea), a pathogenic myxosporidian of the digestive duct of the gilthead sea bream (Sparus aurata) in pisciculture. J. Eukaryot. Microbiol., 2006, 53, S20.

Kaltner H., Stippl M., Knaus M. \& El-Matbouli M. Characterization of glycans in the developmental stages of Myxobolus cerebralis (Myxozoa), the causative agent of whirling disease. J. Fish. Dis., 2007, 30, 637-647.

Karagouni E., Athanassopoulou F., Tsagozis P., Ralli E., MousTAKAREAS T., LYTRA K. \& DOTSIKA E. The impact of a successful anti-myxosporean treatment on the phagocyte functions of juvenile and adult Sparus aurata L. Int. J. Immunopathol. Pharmacol., 2005, 18,121-132.

Kent M.L. \& Hedrick R.P. PKX, the causative agent of proliferative kidney disease (PKD) in Pacific salmonid fishes and its affinities with the Myxozoa.J. Protozool., 1985, 32, 254-260.

Kent M.L., André́ K.B., Bartholomew J.L, El-Matbouli M., Desser S.S., Devlin R.H., Feist S.W., Hedrick R.P, Hoffmann R.W., Khattra J., Hallet S.L, Lester R.J.G., Longshaw M., Palenzuela O., Siddall M.E. \& Xiao C. Recent advances in our knowledge of the Myxozoa. J. Eukaryot. Microbiol., 2001, 48, 395-413.

Koehler A., Romans P., Desser S. \& Ringuette M. Encapsulation of Myxobolus pendula (Myxosporidia) by epithelioid cells of its cyprinid host Semotilus atromaculatus. J. Parasitol., 2004, 90, 1401-1405.

LEINO R.L. Reaction of rodlet cells to a myxosporean infection in kidney of the bluegill, Lepomis macrochirus. Can. J. Zool., 1996, 74, 217-225.

Lom J. \& Dyková I. Myxozoan genera: definition and notes on taxonomy, life-cycle terminology and pathogenic species. Folia Parasitol., 2006, 53, 1-36.

McArThur C.P. \& SENGUPTA S. 1982 Antigenic mimicry of eel tissues by a myxosporidian parasite. Zeitschrift Parasitenk, 1982, 66, 249-255.

MolnÁr K. Differences between the European carp (Cyprinus carpio carpio) and the coloured carp (Cyprinus carpio baematopterus) in susceptibility to Thelohanellus nikolskii (Myxosporea) infection. Acta. Vet. Hung., 2002, 50, 51-57.

Muñoz P., Sitjà-Bobadilla A. \& Alvarez-Pellitero P. Cellular and humoral immune response of European sea bass 
(Dicentrarchus labrax L.) (Teleostei: Serranidae) immunized with Sphaerospora dicentrarchi (Myxosporea: Bivalvulida). Parasitology, 2000a, 120, 465-77.

Muñoz, P., Alvarez-Pellitero P. \& Sitjà-Bobadilla A. Modulation of the in vitro activity of European sea bass (Dicentrarchus labrax L.) phagocytes by the myxosporean parasite Sphaerospora dicentrarchi (Myxosporea: Bivalvulida). Fish Shellfish Immunol., 2000b, 10, 567-581.

Muñoz P., Cuesta A., Athanassopoulou F., Golomazou H., Crespo S., Padrós F., Sitjà-Bobadilla A., Albiñana G., Esteban M.A., Alvarez-Pellitero P. \& Meseguer J. Sharpsnout sea bream (Diplodus puntazzo) humoral immune response against the parasite Enteromyxum leei (Myxozoa). Fish Shellfish Immunol., 2007, 28, 657-665.

Nichols K.M., Bartholomew K. \& Thorgand G.H. Mapping multiple genetic loci associated with Ceratomyxa shasta resistance in Oncorhynchuus mykiss. Dis. Aquat. Organ., 2003, 56, 145-154, 2003.

Padrós F., Palenzuela O., Hispano C., Tosas O., Zarza C., Crespo S. \& Alvarez-Pellitero P. Myxidium leei (Myxozoa) infections in aquarium-reared Mediterranean fish species. Dis. Aquat. Organ., 2001, 47, 57-62.

Palenzuela O., Alvarez-Pellitero P. \& Sitjà-Bobadilla A. Glomerular disease associated with Polysporoplasma sparis (Myxozoa) infections in cultured gilthead sea bream, Sparus aurata L. (Pisces: Teleostei). Parasitology, 1999, 118, 245-256.

Palenzuela O., Redondo M.J., López E. \& Alvarez-Pellitero P. Cultured sole, Solea senegalensis is susceptible to Enteromyxum scophthalmi, the myxozoan parasite causing turbot emaciative enteritis. Parassitologia, 2007, 49, 73.

Pauley G.B. Fish sporozoa: Extraction of antigens from Myxosoma cerebralis spores which mimic tissue antigens of rainbow trout (Salmo gairdneri). J. Fish Res. Bd. Can., 1974, 31, 1481-1484.

Quigley D.T.G. \& McArdle J.F. Management and control of proliferative kidney disease (PKD) in a freshwater Atlantic salmon (Salmo salar L.) farm in Ireland: a case history. Fish. Vet. J., 1998, 2, 1-12.

Quiroga M.I., Redondo M.J., Sitjà-Bobadilla A., Palenzuela O., Riaza A., Macías A., Vázquez S. Pérez A., Nieto J.M. \& Alvarez-Pellitero P. Risk factors associated with Enteromyxum scophthalmi (Myxozoa) infection in cultured turbot (Scophthalmus maximus L.). Parasitology, 2006, 133, 433442.

Redondo M.J., Palenzuela O., Riaza A., Macías M.A. \& Alvarez-Pellitero P. Experimental transmission of Enteromyxum scophthalmi (Myxozoa), an enteric parasite of turbot Scophthalmus maximus. J. Parasitol., 2002, 88, 482488.

ReITE O.B. The rodlet cells of teleostean fish: their potential role in host defence in relation to the role of mast cells/eosinophilic granule cells. Fish Shellfish Immunol., 2005, 19, 253-267.

RYCE E.KN. Factors affecting the resistance of juvenile rainbow trout to whirling disease. Ph. D. thesis, Montana State University, Bozeman, MT, 2003.

SAUlnier S. \& DE KinKelin P. Antigenic and biochemical study of PKX, the myxosporean causative agent of proliferative kidney disease of salmonid fish. Dis. Aquat. Organ., 1996, 27, 103-114.

Schisler G.J., Myklebust K.A. \& Hedrick R.P. Inheritance of Myxobolus cerebralis resistance among $\mathrm{F}_{1}$ generation crosses of whirling disease resistant and susceptible rainbow trout strains. J. Aquat. Anim. Health., 2006, 18, 109-115.

SEVERIN V.I.C. \& El-Matbouli M. Relative quantification of immune-regulatory genes in two rainbow trout strains, Oncorbynchus mykiss, after exposure to Myxobolus cerebralis, the causative agent of whirling disease. Parasitol. Res., 2007, 101,1019-1027.

SIAU Y. Observation immunologique sur des poissons du genre Mugil parasites par la Myxosporidie Myxobolus exiguus Thélohan, 1895. Zeitschrift Parasitenkund, 1980, 62, 1-6.

Sitjà-Bobadilla A. \& Alvarez-Pellitero P. Pathologic effects of Sphaerospora dicentrarchi Sitjà-Bobadilla and AlvarezPellitero, 1992 and S. testicularis Sitjà-Bobadilla and AlvarezPellitero, 1990 (Myxosporea: Bivalvulida) parasitic in the Mediterranean sea bass Dicentrarchus labrax L. (Teleostei: Serranidae) and the cell-mediated immune reaction: a light and electron microscopy study. Parasitol. Res., 1993, 79, 119-129.

Sitjà-Bobadilla A., Redondo M.J., Macías M.A., Ferreiro I., Riaza A. \& Alvarez-Pellitero P. Development of immunohistochemistry and enzyme-linked immunosorbent assays for the detection of circulating antibodies against Enteromyxum scophthalmi (Myxozoa) in turbot (Scophthalmus maximus L.). Fish Shellfish Immunol., 2004, 17, 335-345.

Sitjà-Bobadilla A., Redondo M.J., Bermúdez R., Palenzuela O., Ferreiro I., Riaza A., Quiroga I., Nieto J M. \& Alvarez-PelLITERO P. Innate and adaptive immune responses of turbot, Scophthalmus maximus (L.) following experimental infection with Enteromyxum scophthalmi (Myxozoa: Myxosporea). Fish Shellfish Immunol., 2006, 21, 485-500.

Sitjà-Bobadilla A., Diamant A., Palenzuela O. \& Alvarez-PelLITERO P. Host factors and experimental conditions on the horizontal transmission of Enteromyxum leei (Myxozoa) to gilthead sea bream (Sparus aurata L.) and European sea bass (Dicentrarchus labrax L.). J. Fish Dis., 2007a, 30, 24350 .

Sitjà-Bobadilla A., Palenzuela O., Riaza A., Macías M.A. \& Alvarez-Pellitero P. Protective acquired immunity to Enteromyxum scophthalmi (Myxozoa) is related to specific antibodies in Psetta maxima (L.) (Teleostei). Scand. J. Immunol., 2007b, 66, 26-34.

Sugryama A., Yokoyama H. \& Ogawa K. Epizootiological investigation on kudoosis amani caused by Kudoa amamiensis (Multivalvulida: Myxozoa) in Okinawa prefecture, Japan. Fish Pathol., 1999, 34, 39-43.

Wagner E., Arndt R. \& Brough M. Comparison of susceptibility of five cutthroat trout strains to Myxobolus cerebralis infection. J. Aquat. Anim. Health, 2002, 14, 84-91.

Yasuda H., Ooyama K., Nakamura A., Iwata K., Palenzuela O. \& Yoконама H. Occurrence of the myxosporean emaciation disease caused by Enteromyxum leei in cultured Japanese flounder Paralichthys olivaceus. Fish Pathology, 2005, 40, 175-180. 